\title{
Was Ian Milner a Spy? A Review of the Evidence
}

\section{Denis Lenihan}

The first duty of an underground worker is to perfect not only his cover story but his cover personality. Kim Philby, My Silent War (p. 180).

A recent re-reading of James McNeish's Dance of the Peacocks, and in particular his views on Ian Milner, has prompted some research on what others have said about Milner, particularly as to whether or not he was a spy. The outcome is that despite the existence of sufficient evidence showing that Milner was indeed a spy, McNeish and others decline to accept the fact. As the evidence emerged at various times and places over the last ten years, it is best to deal with the various issues chronologically.

Ian Milner was born in 1911 in Oamaru, where his father was the rector of Waitaki Boys' High School. After graduating from Canterbury University College, he went to New College Oxford in 1934 on a Rhodes scholarship and read philosophy, politics and economics. He spent nearly two years (1937-39) in the United States as a Commonwealth Fund Fellow, and after a brief period in New Zealand became a lecturer in the Department of Political Science at the University of Melbourne. In 1945, at the urging of Paul Hasluck, the head of the Division, he took up a temporary position in the Post-Hostilities Planning Division of the Department of External Affairs (as it was then called) in Canberra. He was there for nearly two years before being appointed in 1947 as a political affairs officer in the UN Security Council Secretariat in New York. In July 1950 he went to Prague, ostensibly so that his wife - Margaret Leigh Trafford (generally known as Margot), whom he had married in 1940 could receive special medical treatment. Milner became a lecturer in English at the Charles University, and apart from visits abroad, remained in Prague until his death in 1991. He and his wife were divorced in 1958 after Margot found out about his longstanding affair with a Czech diplomat (and her friend) 
Jarmila Fruhaufova, whom he had first met at the UN in New York. Milner and Fruhaufova were married in $1958 .^{1}$

During the economic depression of the 1930s - and apparently because of it - Milner adopted what O'Sullivan called a 'Marxist socialism' (p. 13). While Milner made no secret of his beliefs, he later claimed that he had never been a member of the Communist Party - a claim supported by his first wife, who was herself a member. As we shall see, his claim was later disputed, it being argued that he was a Party member at least from his time in Melbourne. It is not, however, disputed that he was successively involved in a number of leftwing organisations: the Friends of the Soviet Union at Canterbury University College, the Labour Club at Oxford, the Institute of Pacific Relations in the USA during his time there after Oxford, the Peace and Anti-Conscription Council in Wellington and the Soviet Friendship League and similar bodies in Melbourne.

Milner first came to public notice when he was mentioned during the proceedings - and, more prominently, in the report - of the Royal Commission on Espionage, which had been established by the Australian Government in 1954 following the defection of Vladimir Petrov, then Third Secretary (and MVD/KGB Resident) at the USSR Embassy in Canberra, and his wife Evdovika Petrov, also of the MVD/KGB who was also employed at the Embassy and who assisted her husband with his espionage work. Milner's name and some of the allegations that he was a spy were raised by or with a number of witnesses at public sessions of the Commission: Mr and Mrs Petrov, a journalist named Rex Chiplin, his former student and External Affairs colleague (and fellow-spy) Jim Hill, and Wally Clayton. In its report in September 1955, the Royal Commission found that Milner had been 'in possession of secret documents in circumstances which gave rise to grave suspicion as to the use he had made of them'; and that on the basis of the Petrovs' testimony and 'other material which we have seen', Milner had given information to the USSR via Wally Clayton, a leading member of the

\footnotetext{
${ }^{1}$ These and other details of Milner's life and activities are taken from the works cited below by Vincent O'Sullivan, Desmond Ball and David Horner, and Richard Hall.
} 
Communist Party of Australia (Manne, 2004). (Clayton was born in Ashburton and educated at Christ's College.)

Nearly six months later, on 1 March 1956, Milner lodged a 'Personal Statement' concerning the Royal Commission with the British Embassy in Prague to be forwarded to the Australian Government. ${ }^{2}$ In the statement, Milner said that the Royal Commission's finding concerning him was 'entirely untrue, defamatory, and very shocking to me'. He denied that he had given information to the USSR and said that to the best of his recollection he had never met Clayton. Not unreasonably, he fastened on some of the inconsistencies in the Petrovs' accounts of him and the vagueness of the reference to 'other material which we have seen'. He also noted some factual inaccuracies in the report and complained that he had been given no opportunity to rebut the allegations. On 9 April 1956, he issued a press statement which is a shorter version of the Personal Statement. ${ }^{3}$

Milner was of course quite correct in complaining that by not having the allegations put to him - or at least some effort being made to get in touch with him - he had been denied what is now called 'procedural fairness' but which once had the better name of natural justice. If the Royal Commission had got in touch with Milner, it may also have avoided the embarrassment of the factual errors about him which appeared in the report. That having been said, however, many of Milner's other assertions are highly questionable.

In his Personal Statement, Milner says that

Before reading the paragraphs concerning me in the Report [of the Royal Commission], I had no knowledge whatsoever that allegations of a most grave nature had been made against me and the good name of my family. I had read accounts from time to time of the lengthy proceedings of the Commission in the official Newsletter received from Australia House, and in the London Times. But from no source of news available to me did I gather any indication that I was to be charged with having, or

\footnotetext{
${ }^{2}$ The Statement is reproduced in O'Sullivan, pp. 188-96.

${ }^{3}$ The press statement is reproduced in McNeish, pp. 420-2.
} 
'probably' having, divulged official secret information... This charge, made without any advice that my conduct while an officer of the Department of External Affairs was under examination, or without there being accorded me any opportunity of reply, is entirely untrue.

In his memoirs, he says that (p. 186)

I had known from newspapers, and from clippings sent from friends in Australia, that the Commission had examined a large number of persons suspected of being connected in some way with the alleged leakage of official secret material from the Department of External Affairs to a person said to have been a Russian agent. The Commission's work was based primarily on the 'Petrov papers', the material obtained by the Australian Intelligence Service from the Russian defector Petrov, a notorious alcoholic, and his wife. (emphasis added).

It seems highly likely, to put it no higher, that the clippings mentioned Milner.

Yet he claimed in his Personal Statement that '[b]efore reading the paragraphs concerning me in the Report, I had no knowledge whatsoever that allegations of a most grave nature had been made against me and the good name of my family' (emphasis added). As David McKnight observes, [Milner] 'explained the lateness of his statement as being due to the fact that no one told him that he was mentioned in the course of the Royal Commission, which is unbelievable' (p. 74).

There is a further source of evidence that Milner knew what was happening at the Royal Commission: his first wife. According to the Australian historian Frank Cain, Mrs Margot Milner (pp. 60-66)

flew to New Zealand via Sydney in 1954 at the time when the Petrovs were making their revelations about lan Milner and others...On her return to Prague, Margot attempted to persuade Ian to travel to Australia to ensure that his explanation of events would be put to [the Royal Commission]. He rejected the suggestion, saying that he did not wish to travel without Jarmila and that he would first make a statement to the Prime Minister through the British embassy in Prague and then give a personal interview if requested. 
In 1984, under the thirty-year rule, the transcripts of the evidence given in confidence to the Royal Commission were released. They showed that the Secretary of the Department of External Affairs, John Burton, had told the Royal Commission that he had become aware in 1948 that Milner had been a security risk while in the Department and that he had been associated with the Communist Party. (The significance of 1948 will become apparent below.) Milner was telephoned in Prague but he again denied leaking any material (Hall, p. 205).

It was only after Milner's death in 1991 that the allegations that he had been a spy gathered force. The Australian journalist and author Richard Hall (19372003) wrote an obituary for The Independent in London in which he described Milner as a spy. Later that year, Hall's book on Milner, The Rhodes Scholar Spy, was published. It had clearly been some time in the making. In the Acknowledgements of the book - one of several he wrote about espionage Hall lists seven Australian libraries or archives which helped him; four in the United Kingdom; three in the USA; and one in New Zealand. He adds that 'many people' in six countries, and Milner in Prague, helped with reminiscences, although 'most preferred not to be named'. From various clues, particularly in the material released in 1984, Hall guessed that Milner had been brought undone by the activities of code-breakers. Hall's interview with Milner was off-the-record, but it emerged (not from Hall) after Milner's death that when Hall told him what he had discovered, Milner responded: 'If what you say is true, then things look bad for lan Milner' (quoted in Ball and Horner, p. 328).

As we shall see below, Hall's book came in for some strong criticism from Milner's champions. Ball and Horner provide a more balanced view, describing Hall's book in their preface as 'a path-breaking effort relating the decryption operation to the uncovering of espionage activities in Australia in 1944-48, but this is a journalistic work, undocumented, marred by some important inaccuracies, and substantially incomplete'.

The Australian historian Frank Cain was an early defender of Milner, and his 
piece published in 1994 but evidently written earlier set out to trace 'the events in the process that led to lan Milner being framed as a spy and thereby becoming one of Australia's early Cold War victims'. He concluded that 'the Milner allegation turns on the extremely scanty information MI5 gave to the Australian government and on which it never elaborated. It is likely that it never will.' At the Royal Commission, 'Milner's name was bandied about and the implication that he was the spy went uncontested because he was not represented before the Commission'. Moreover '[h]e was definitely not the superannuated spy of Hall's construct.'

One of the footnotes in Cain's article referred to the forthcoming publication of Milner's memoirs, edited by Vincent O'Sullivan. The memoirs were published in 1993, and of the twenty-seven pages of O'Sullivan's introduction, no fewer than twelve of them are devoted to the spying allegations. O'Sullivan suggested that the interest of Hall's book 'was not that it demonstrated a case, so much as told a ripping yarn. Here was the Oxford spy we had been waiting for, the privileged colonial boy.' He correctly observed that 'although Hall several times asserts that Milner's name was exposed by the codebreakers, he produces no factual evidence that this was so'; and he went on to note the discrepancies in the Petrovs' evidence and the 'gossip and assumption' used by Hall. All this was done with considerable style: 'I Spry with my little eye' O'Sullivan wrote at one point, a nice pun on the name of the Director General of ASIO at the time, Brigadier Spry.

The factual evidence was not long in appearing, and in two places almost simultaneously. In Washington in October 1996, the US National Security Agency began to release (and to put on the web) the Venona documents, intercepted and decrypted cables sent between Moscow and various Soviet embassies around the world (including Canberra) in the period from 1943-48. Late in the same year, documents from the Czech Ministry of the Interior were released. They concerned Agent 9006, A Jansky, the codename of Milner, and even though they comprised only 15 pages of what had originally been a 164 page file, they were sufficient to show why Milner had come to Prague in 1950 and what he had been doing there, apart from lecturing at the Charles 
University.

Both lots of evidence were damning, to repeat the word used by the Australian historian Phillip Deery, who appears to have been the first to have published his conclusions drawing on both sets of documents (pp. 9-12). The Venona documents recorded Milner telling Clayton 'many interesting things' in September 1945, and Clayton receiving in March 1946 two top secret British reports which were photographed and transmitted to Moscow. Milner had had access to the reports. The Prague material recorded Milner's services to the Communist cause while he was in Canberra, noted that he had re-established contact with the KGB in 1947 and said that he was 'won for cooperation in March 1949' that is, by the Czech secret service. While he was with the UN, Milner provided reports on what was happening. The material also recorded that in 1950 the Czech authorities received information about 'a possible repression' against Milner and the decision was made to relocate him in one of 'the people's democracies'. His wife's medical treatment was 'a pretext', and it was on the recommendation of the Czech authorities that Milner resigned from the UN. Further, from May 1954 'He was directed to work among university professors and scientific workers ... our collaborator was used for reporting on universities' personnel who had contacts with the USA and Great Britain'. His handlers praised the way he carried out his tasks, at least until 1960.

The Czech authorities were well informed about moves against Milner in 1950, although these had in fact started in 1948 when the relevant Venona cables were decrypted and identified Milner as a spy. At the end of that year, he was 'placed under close surveillance by the FBI'. This apparently continued for the next 18 months - Milner went to Prague in July 1950 although the investigation was not closed until June 1952. The file noted that the investigation 'failed to develop any information reflecting Milner was engaged in espionage activities in the United States'. He was not under surveillance for his first two years in New York (1947 and 1948) and in any event the target of his espionage activities was the United Nations rather than the US. As to the 'possible repression', Aaron Fox has noted that this may 
have meant an investigation, and that in the middle of 1950 the FBI was considering an interview with Milner.

Further and better particulars, as the lawyers say, of the Venona material, became available in 1998 with the publication of Breaking the Codes: Australia's KGB Network 1944-1950 by Desmond Ball and David Horner, of the Strategic and Defence Studies Centre at the Australian National University in Canberra. They had begun work on the subject in the late 1970s, and as they indicated in the Preface to their work, 'the release of the (Venona) decrypts has enabled us to complete the story with authoritative evidence'.

Before discussing what Ball and Horner say about the decrypts, it is convenient to deal with what they and others have to say about the circumstances in which Milner and his wife went to Czechoslovakia in mid1950, in particular what other relevant events were occurring at that time. Milner's fellow spy and former colleague in External Affairs, Jim Hill (they were still in touch), was posted to London in 1950 at the suggestion of MI5, presumably in the expectation that he might unwittingly help them to find spies in the UK. He did not do so, and after three months Hill was interrogated by Jim Skardon, the MI5 man who had a few months earlier got Klaus Fuchs to confess. Hill made no admissions, however, and in August 1950 was sent back to Australia. ${ }^{4}$

On 1 November 1949, Kim Philby arrived in Washington and took up his job as liaison officer between MI6 and the US intelligence agencies. He was briefed about Venona. One of the leading US cryptanalysts, Meredith Gardner, later told Peter Wright 'how a young pipe-smoking Englishman named Philby used to regularly visit him and peer over his shoulder and admire the progress he was making' (p. 18). Consequently in the first half of 1950 several spies were arrested as they preparing to disappear behind the

\footnotetext{
${ }^{4}$ See Ball and Horner, pp. 307-11.
} 
Iron Curtain (the Rosenbergs, for example) or others, quicker off the mark, did in fact disappear (some of the Rosenbergs' colleagues). ${ }^{5}$

Against this background, Milner's move to Prague when all this was going on, and three weeks after Hill's interrogation, makes perfect sense. Not much noted at the time, or indeed since, was the presence in Prague of some old Party mates from Melbourne. Phillip Deery has recently written about 'a small community of left-wing Australians living in or travelling through Prague' around 1950. The community included 'Beth and Ken Gott, Noel Ebbels, lan Turner, Bernard Smith, lan and Margot Milner, Kurt and Blanche Mertz, Jack Hutson and Max Nicholson' and Stephen and Nita Murray-Smith. Of these, Murray-Smith (1922-88), Gott (1923-90) and Ebbels lived and worked in Prague at that time; they and Turner (1922-78), and perhaps some of the others, were members of the Communist Party and students at the University of Melbourne during or at the end of the war. While at least some would have been known by both the Milners, neither side seems to have acknowledged the existence of the other. ${ }^{6}$

To return to the Venona decrypts about Australia, we learn from Ball and Horner in a wealth of documented detail that (to concentrate on Milner) the decrypts made in 1948

revealed that copies of two secret British reports which had been made available to the Australian Department of Defence, and by it to External Affairs, had been sent by the Soviet Embassy in Canberra to Moscow in March 1946. The reports had at the relevant time been in Milner's possession, and documentary evidence of his possession of them was available. The documents were numbered by the Department of Defence as a security precaution $^{7}$ and the Soviet Embassy transmitted all the details of the

\footnotetext{
${ }^{5}$ See Ball and Horner, p. 20.

${ }^{6}$ For Gott, Murray-Smith and Turner, see McLaren, especially chapters 3 and 5 . Milner is not mentioned in the index (neither is Petrov, even more curiously), and none of the trio or others in the community in Prague are mentioned in Milner's Memoirs.

${ }^{7}$ For security reasons, sensitive government documents such as these are produced in limited quantities, each copy is numbered, and those having access to each copy have to sign for it; so that if a copy goes astray if may be possible (as in this case) to identify the copy and who had possession of it; the system used also to apply in Australia to Cabinet documents,
} 
documents, including their numbers and how the Embassy obtained them. As Ball and Horner show (pp. 281-2), quoting from official records, at the relevant time the documents were (legitimately) in Milner's possession: in particular, copy number 109 of the document 'Security in the Eastern Mediterranean and the Eastern Atlantic' had been signed out by Milner on 6 March 1946 and returned on 28 March 1946. That copy, with the identifying number 109 included, was transmitted to Moscow by the Soviet Embassy in Canberra on 19 March 1946. The Embassy also recorded in the cable that it had had possession of the original for 35 minutes, having obtained it from 'Klod', later identified as Wally Clayton. Ball and Horner reproduce (p. 204) page one of the translated decrypt of the cable. They do not deal in such detail with the other document included in the cable, but it is impossible to resist their conclusion that Milner provided that too.

In view of what follows, it is necessary to backtrack a little and look at Milner's previous access to another copy of the document in question. Ball and Horner also show from the official records that Milner signed out copy number 110 on 15 November 1945 and returned it on 19 February 1946.

All this looks pretty conclusive, and might have been thought sufficient to persuade Milner's supporters that he had deceived them, and perhaps himself. But it was not enough for the author James McNeish and the historian Aaron Fox, both New Zealanders.

Paradoxically, McNeish provides yet further evidence of the suddenness of Milner's defection and the extent to which it was orchestrated by the Czechs. In 1949 Milner and his wife visited New Zealand. They travelled via Australia, and went to Canberra to 'take soundings for a job at the Australian National University'. He was also applying for academic posts at Oxford and London. In Wellington he stayed with his old friends the Bertrams 'telling them his one wish is to get back to the southern hemisphere with Margot' (p. 294). 
Assuming all this to be true, his sudden decision to go to Prague a few months later is explicable only by the intervention of new factors, such as those we have seen. McNeish also quotes Margot Milner as saying that the reason she went to Slovakia for treatment in 1950, after her arthritis attack in Switzerland, was that Jarmila suggested it; Jarmila provided the names of the specialists and the spas appropriate for her cure' (p. 409). She suggested further that 'Ian's initial teaching job at Charles University was arranged through the UN office in Prague' (ibid.) - where Jarmila worked.

Jarmila was as much watchdog as wife after their marriage, suggesting that it was part of her job as Party member to keep an eye on her husband. Even before their marriage, as noted above, he would not (could not?) travel without her. He 'was seldom out of Jarmila's sight', McNeish records (p. 408):

He attended conferences and gave interviews by the score in their more than thirty years of marriage. Jarmila so far as one can tell was present at every one. Until the 1980s he never left Prague without her. She accompanied him on every trip, made every social engagement: she was the hidden policeman who monitored everything he did and said.

When Milner and his wife were in New Zealand for 11 months in 1971, no one seems to have been able to speak to Milner alone: 'Jarmila was always there' (p. 334).

Part of McNeish's defence of Milner against the spying evidence involves rewriting history, the better to make it appear for Milner. Another part is to ignore those parts of history which go against Milner. An example of the first is his description of the Royal Commission on Espionage, the 'real justification' of which 'appears to have been a desire by the head of ASIO, Colonel Spry, to rehabilitate his organisation in American eyes'. 'The Commission proved a damp squib.' 'Vladimir Petrov was a cipher clerk...' (p. 322). Then, notwithstanding the other comments, 'Petrov's importance to the West was his disclosure that Burgess and MacLean were not homosexuals on the run but long-term Soviet agents who had been recruited at Cambridge University' (p. 457). Finally, 'Since the Royal Commission ceased work, an industry has 
grown up around its findings that continues to generate in Milner's case an expanding literature, a sea of speculation and commentary by uninformed minds, bearing as much relation to the historical facts as footprints in the sand' (pp. 322-23).

Readers who want a more accurate and balanced account of the Royal Commission should read Robert Manne's The Petrov Affair, where they will find that the suggestion for a Royal Commission came from the SolicitorGeneral, not ASIO; that the Commission, among other matters, identified several spies and others who had assisted the Soviet Embassy; that Petrov was a full colonel in the KGB; and that the importance of the two Petrovs to the West was their ability to provide valuable information on Soviet codes and cryptanalytic practices, and to identify both 'virtually the entire command structure' of the KGB and 'upwards of five hundred Soviet intelligence officers' who had served abroad. ${ }^{8}$

As to Milner, McNeish does not engage with Ball and Horner's careful, welldocumented explanation of what occurred in March 1946 which was outlined earlier in this piece. While their book is listed in the select bibliography, they are otherwise mentioned only in one footnote (p. 457) without comment. In another footnote on the same page, McNeish avoids engaging with Hall's arguments by haughtily dismissing the book as 'void of sources... a mix of fact and fantasy afloat on a sea of speculation'.

Milner, it will be recalled, had copy number 110 of the Western Mediterranean document from 15 November 1945 to 19 February 1946, and copy number 109 from 6 March 1946 to 28 March 1946. McNeish claims in discussing Milner that '[t]he worst that can be said of him, during his eighteen months with the UN division in Canberra (1945-6), is that he was guilty of an indiscretion or a misjudgment.' Further, the (Royal) Commissioners 'got the wrong man.' McNeish records only the details of copy number 110 and blithely concludes that, since this was not the copy that was transmitted to

\footnotetext{
${ }^{8}$ See especially Chapters $1,4,12$ \& 14.
} 
Moscow, 'the only piece of hard evidence against lan Milner, suggesting that he spied for the Soviets, turns out to be a case of mistaken identity' (pp. 3235).

McNeish does not explain why he ignores the incriminating record of copy number 109, even though, as noted, he refers to Ball and Horner's book. McNeish does not seem to have examined the relevant archival documents himself and relies on the New Zealand historian Aaron Fox, who has made such an examination. Fox likewise quotes only the record concerning copy number 110 and ignores the incriminating record - notwithstanding that he draws the reader's attention in footnote 54 to the very pages in Ball and Horner's book which record both of Milner's borrowings. Fox thus concludes that '[t]he Venona documents therefore fail to prove Milner's complicity in treasonable activity, still less that he knowingly passed secrets to a Soviet spymaster' (p. 121).

McNeish (but not Fox) adopts the same approach in dealing with the Czech archives about Milner. As noted above, these record his services to the Party in Australia and the US, the true circumstances concerning his move to Czechoslovakia and the continued services he rendered in that country to the StB (the Czech State Security Service) by in effect spying on his colleagues. Fox has web references to the material and has no major reservations about its authenticity, concluding that Milner's 'own activities as an StB informant highlighted the Faustian bargain which his own ideological convictions, communist associations and academic career forced upon him behind the Iron Curtain' (p. 124).

McNeish has seen the Prague material. At pages 467-8, he records that he examined 'Milner's Interior Ministry file' in Prague in 1999, with the help of an interpreter. He found it to be a three page document which was 'a mixture of fact, distortion, error, surmise, innuendo and exaggeration'. Again the reader is given no help in discerning fact from error, save for one example where it is asserted that the statement on the file that Milner was being paid 25,000 Czech crowns a month is 'ludicrous'. Whether Milner got thirty pieces of silver 
or some lesser number might appear to most readers to be a secondary consideration. Curiously, also on page 468 is a description of Fox's piece as 'an informed discussion' of Milner vis-à-vis Western Intelligence agencies.

McNeish goes further, however, than simply casting doubt on the accuracy of the file. 'The file is not forged but appears concocted; it is possibly a plant, as happened in 1992 with Jan Kavan, the future Czech Foreign Minister.' But as his biography on the web shows, Kavan as an exile, a dissident, and later a politician attracted much opposition in his own country, so that there was some explanation for the concoctions about him. Why should any Czech agency wish to concoct material against Milner, and then mix it in with true material?

Elsewhere in his book, however, McNeish does concede that Milner informed to the StB on his colleagues in Prague (that much of the Security file, at least, is apparently accurate), but the defence here is 'he tells the police nothing that is not a matter of public knowledge' (p. 313) One source for this assertion is as follows: 'Milner's Czech colleagues I spoke to maintained that any information he provided was innocuous. Professor Martin Hilsky, his severest critic, said: "Some members of the department did not trust him, but no one was hurt or harmed by anything he said. To me this is crucial"'(p. 456). How Professor Hilsky could assert this so confidently is not clear, and in any event he is talking only about the English Department at Charles University. Milner's brief was much wider than this: as noted above, it embraced 'reporting on universities' personnel who had contacts with the USA and Great Britain.' Another source, Dean Prochazka, told McNeish that 'I have never come across any of these so-called "activities" concerning lan'; but his objectivity is doubtful, as he also told McNeish that 'I loved him. I loved that man' (p. 407). And telling his masters what was public knowledge would hardly have earned him their praise ('his collaboration was highly valued').

There is one further aspect of Milner's activities in Australia which has not received the attention it warrants, and that is what looks like his role in talent spotting other members of the Communist Party in Melbourne for the 
Department of External Affairs. According to Ball and Horner, Milner joined the Melbourne University branch of the Communist Party as a secret member in March 1940, soon after his arrival. At the end of that year, when his wife Margot arrived in Melbourne, the branch had only about 14 members. Milner had known some of them in Wellington, one being Noel Counihan, who had been arrested in New Zealand as a 'subversive' and deported. ${ }^{9}$ The numbers in the branch built up to about 30 (mainly students) in 1942 (when the Party was illegal) and to about 100 by 1944 (when it had become legal again). Ball and Horner record (p. 259) an account given to ASIO in 1954 of Milner's methods of recruitment. Individual students would be selected and cultivated, including by invitations to the Milners' flat in North Melbourne, and later they would be invited to Party study groups or branch meetings. Milner would arrange to meet the recruits at street corners and escort them to various secret meeting places; such melodrama no doubt increased the appeal of Milner and the Party to some students. His wife, by contrast, 'openly courted recruits from the students'.

At least three members of the Party in Melbourne - apart from Milner himself - ended up in the Department of External Affairs in Canberra, and it is a reasonable inference that Milner had some influence in their career choice. The most prominent example is Jim Hill, whose father - like Milner's, curiously - was an exceptional school headmaster. Hill graduated in law from the University of Melbourne in 1940, having been a student of Milner's. He had joined the Communist Party (Moonee Ponds branch) in 1938 or 1939, and in 1945 after war service followed Milner - on his introduction, according to one source - into the Post-Hostilities Planning Division of External Affairs. Like Milner, he was recorded on the Venona transcripts as giving classified material to Clayton for transmission to Moscow. ${ }^{10}$

There were two other University of Melbourne graduates who also joined the Communist Party and later External Affairs. Dorothy Jordan joined the Party

\footnotetext{
${ }^{9}$ See Ball and Horner (pp. 258-9), except the reference to Noel Counihan, which is found in McNeish (p. 272).

${ }^{10}$ See Ball and Horner (pp. 262-3), except the reference to Hill having been Milner's student, which is found in Manne ( $p$.235).
} 
(University branch) in 1942, graduated with an arts degree in 1944 and after working with the Department of Post-War Reconstruction in Melbourne joined External Affairs in Canberra in 1945. She too was mentioned in the Venona material, Canberra telling Moscow in 1945 that Wally Clayton expected to get secret material from her. There was no evidence that he ever did so, and in any event Jordan left the Public Service in 1947 on her marriage to Ric Throssell (Ball and Horner, pp. 266-8). It is a matter of some irony that while Australian married women at that time - and indeed until the middle 1960s could not be permanently employed in the public service, there were evidently no such restrictions in the USSR public service, as Mrs Petrov's employment in the KGB attests.

June Barnett joined the Party during the war and graduated with an arts degree in 1947, joining the Department as a diplomatic cadet in 1948. The ubiquitous Wally Clayton approached her in 1950 for assistance, but she told the Royal Commission that she declined to help him (McKnight, pp. 80-1).

To these and other Party members at that time, Milner must have seemed almost a charismatic figure: only in his thirties, an acting head of department, a Rhodes scholar, someone who had spent time in the USSR and the USA, with an outspoken wife who was also a Party member. He was also no armchair Communist, at that time being involved with the Council for Civil Liberties, the Australia-Soviet Friendship League, the Victorian Youth Parliament, the Civilian Air Raid Defence Committee (which despite its name, was anti-government) and the Volunteer Defence Corps. Milner thus may have to some extent resembled the legendary Arnold Deutsch, who was responsible for the recruitment of Philby and other members of the Cambridge group; and Anthony Blunt, who as a Fellow of Trinity College Cambridge also had an impressive record as a Party talent spotter. ${ }^{11}$

\footnotetext{
${ }^{11}$ See Costello and Tsarev, pp. xvi and 192-3 for Deutsch, and p. 246 for Blunt. Ball and Horner suggest (p. 255) that 'it is likely that... [Milner] became a secret member of the Oxford University Branch of the Communist Party during his stay there'. If so, he may have been recruited by Deutsch, who at that time played a 'key role in the recruitment of most members of the Cambridge and Oxford groups', according to Costello and Tsarev (p. 457, n. 34); but as
} 
A reasonable question at this point is why Milner apparently did not continue his Party or left-wing activities following his move to Canberra in 1945. One former Party member in Canberra told ASIO in 1959 that both Milner and Hill 'carefully refrained from mixing in ordinary Communist circles in Canberra.....Although at the time I concluded that they had left the party I now believe that they were acting on instructions in not joining in the local Communist activities.' Quoting a Party source, David McKnight reports that Milner and Hill 'held the kinds of jobs that made them part of a class of CPA membership that was undercover' (p. 190).

To end this piece where it began, notice how in his various roles Milner perfected his cover personality. At the University of Melbourne, according to Manning Clark, he adopted 'the bourgeois principle of impartiality and detachment', once virtually apologising to Clark for letting himself go by describing the High Court as an 'arm of conservatism in Australia' (O'Sullivan, p. 22). In Canberra, one former colleague told Richard Hall, Milner was 'the External Affairs type...chess, music, cautious and civilised.' He blended into the background at the UN also: 'just another international civil servant' and '... a bit of a wimp. Never associated him with strong opinions.' were two of the comments made to Hall by Milner's former colleagues, who this time are named (pp. 136, 167-8). Finally, in Prague (as McNeish's chapters 32 and 33 portray him) he is the scholar, the eminent translator, the well-liked teacher.

Philby would have approved.

\section{Works Cited}

Ball, Desmond and David Horner. Breaking the Codes: Australia's KGB Network 1944-50. Sydney: Allen and Unwin, 1998.

Cain, Frank. 'The Making of a Cold War Victim'. Overland 134 (1994), 60-66.

Deery, Phillip. 'Cold War Victim or Rhodes Scholar Spy? Revisiting the Case of Ian Milner'. Overland 147 (1997), 9-12.

they also note (p. 246), 'None of the members of the Oxford network have ever been positively identified' - yet, one might add. 
Deery, Phillip. 'An Australian Communist in Prague'. The Hummer, Publication of the Sydney Branch, Australian Society for the Study of Labour History. Vol. 3, no. 8, Winter (2002).

Department of the Prime Minister and Cabinet. Cabinet Handbook. Fifth Edition, Amended March 2004. At www.pmc.gov.au/guidelines/docs/cabinet_handbook pdf. Fox, Aaron. 'The Pedigree of Truth: Western Intelligence Agencies versus Ian Frank George Milner and William Ball Sutch'. In Trapeznik, Alexander and Aaron Fox (eds) Lenin's Legacy Down Under: New Zealand's Cold War. Dunedin: University of Otago Press, 2004, pp. 115-130.

Hall, Richard. The Rhodes Scholar Spy. Sydney: Random House. 1991.

McKnight, David. Espionage and the Roots of the Cold War: The Conspiratorial Heritage. London: Frank Cass Publishers, 2002.

McLaren, John. Free Radicals: Of the Left in Postwar Melbourne. Melbourne:

Australian Scholarly Publishing, 2003.

McNeish, James. Dance of the Peacocks. Auckland: Vintage, 2003.

McKnight, David. Australia's Spies and Their Secrets. Sydney: Allen and Unwin, 1994.

Manne, Robert. The Petrov Affair. Sydney: Pergamon Press, 1987; revised edition, Melbourne: The Text Publishing Company, 2004.

O'Sullivan, Vincent, (ed). Intersecting Lines: The Memoirs of lan Milner. Wellington: Victoria University Press, 1993.

Philby, Kim. My Silent War. London: MacGibbon and Kee, 1968.

Wright, Peter. Spycatcher - The Candid Autobiography of a Senior Intelligence

Officer. Richmond: William Heinemann, Australia, 1988.

Costello, John and Oleg Tsarev. Deadly Illusions: The KGB Orlov Dossier Reveals

Stalin's Master Spy. London: Century, 1993. 